UDC 384.48

JEL L 83

\title{
MONITORING OF THE STATE AND PROBLEMS OF ACTIVE TOURISM DEVELOPMENT IN UKRAINE
}

\author{
R. Dudyak, PhD \\ ORCID ID: 0000-0001-7934-8234 \\ Lviv National Agrarian University \\ S. Bugil, PhD \\ ORCID ID: 0000-0003-4863-5235 \\ Ivan Franko National University of Lviv \\ J. Shkvarka \\ ORCID ID: 0000-0002-8995-0947 \\ Lviv National Agrarian University
}

https://doi.org/10.31734/economics2019.26.155

\section{Дудяк Р., Бугіль С., Шкварка Я. Моніторинг стану та проблем розвитку активного туризму в Україні}

Сучасна індустрія туризму - одна $з$ найбільш прогресуючих галузей світового господарства. Її розглянуто і як самостійний вид економічної діяльності, і як міжгалузевий комплекс.

Сьогодні туризм став явищем, що увійшло у повсякденне життя майже третини населення планети. Ба більше, на початку XXI ст. туризм за обсягами доходу справедливо посів третє місце серед провідних галузей світової економіки. У багатьох країнах і регіонах він є основним джерелом прибутків.

Особливістю активного туризму є те, що досягнення спортивних результатів тут не є основною метою, а отже, він може бути масовішим, доступнішим для широких верств населення.

Мета означеної галузі туризму полягає в: оздоровленні, відновленні сил, поліпшенні медико-фізіологічних даних за допомогою зміни форм діяльності, дозованого руху, раціонального харчування, нервового розвантаження, підвищення адаптації до незвичних умов; удосконаленні загальної і спеціальної фізичної підготовки, виробленні витривалості, спритності, сили, рівноваги; наданні практичних навичок у доланні перешкод, оволодінні технікою пересування пішки, на лижах, їзди на велосипеді, греблі; психічному вдосконаленні та емоційному збагаченні внутрішнього світу людини, вихованні рішучості, сміливості, впевненості в собі, відповідальності; розширенні краєзнавчого кругозору, вдосконаленні навчально-методичної підготовки, поповненні знань 3 географії, біології, історії, етнографії і культури; засвоєнні теоретичних основ організації і проведення походів, розробки маршрутів, планування роботи туристських гуртків; набутті спортивного досвіду участі в походах.

Водночас швидкі темпи розвитку туризму та його масовість призвели до негативних змін у природному середовищі в окремих регіонах. Розвиток активного туризму в Україні потребує підтримки, узгодженості в межах усієї індустрії.

Ключові слова: активний туризм, туристичний потенціал, туристичні заняття, вплив на довкілля, галузь туризму, екологічний стан, спортивний туризм, туристичні ресурси.

Dudiak R., Buhil S., Shkvarka Y. Monitoring the state and problems of active tourism development in Ukraine

The modern tourism industry is one of the fastest growing industries in the global economy. It is considered both as an independent type of economic activity and as an inter-sectoral complex.

Today, tourism has become a phenomenon that has entered the daily life of almost a third of the world's population. Moreover, at the beginning of the 21 st century, tourism ranked third among the leading sectors of the world economy in terms of income. In many countries and regions, tourism is a major source of income.

The peculiarity of active tourism is that the achievement of sports results is not its main goal, and therefore, it may be more widespread, accessible to the general public.

The studied branch of tourism includes improvement, restoration of forces, improvement of medical and physiological data by means of change of the forms of activity, dosed movement, rational nutrition, mental relaxation, better adaptation to unusual conditions; improvement of general and special physical training, development of endurance, agility, strength, balance; practical skills in overcoming obstacles, mastering the technique of walking, skiing, cycling, rowing; mental improvement and emotional enrichment of the inner world of man, education of determination, courage, self-confidence, responsibility; expanding of the local lore, improving educational and methodological training, updating knowledge of geography, biology, history, ethnography and culture; mastering of the theoretical foundations of organizing and conducting hikes, developing routes, planning the work of tourist groups; gaining of sports experience participating in hiking. 
Despite of the rapid tourism development and its large scale, it has led to negative environmental changes in some regions. The development of active tourism in Ukraine needs support, and coordinated development throughout the country's active tourism industry.

Key words: active tourism, tourism potential, tourist activities, environmental impact, tourism industry, ecological status, sports tourism, tourist resources.

Problem setting. The modern tourism industry is one of the fastest growing industries in the global economy. It is considered both as an independent type of economic activity and as an inter-sectoral complex.

Today, tourism has become a phenomenon that has entered the daily life of almost a third of the world's population. Moreover, at the beginning of the 21 st century, tourism ranked third among the leading sectors of the world economy in terms of income. In many countries and regions, tourism is a major source of income. The number of employees in the tourism industry has also become one of the largest in the world, i.e. it employs more than 260 million people, that is, every 10th employee. Global travel revenues account for more than $\$ 500$ billion annually. Western Europe and the USA receive the highest profits [5].

After Ukraine became independent, the tourist market of our country was just beginning to develop. Today, it is one of the most promising spheres of social and economic development of the country. In Ukraine, the work of the tourist market affects the activity of almost 40 economic sectors of the country and $10-15 \%$ of the population of our country. Thus, tourism is an effective association that can be assist in overcoming of the problems of economic crisis. The main thing is that tourism is an area of activity, where the number of employees does not decrease after the introduction of new methods. Almost $10 \%$ of the country's residents work in the field of Ukrainian tourism. The cost of creating of one job position in this area is 20 times less than in industry, and the turnover of investment capital is 4 times higher [7].

Despite of the rapid pace of tourism development and its large scale, it has led to negative environmental changes in some regions. Contaminated beaches, areas with excessive noise, developed erosion, impoverished landscape became unsuitable for rest and recreation, that is, tourism began to destroy the foundations of its existence. The creation of a new system of ideas concerning development of that industry can change the way of human thinking [4].

However, despite of its great potential, its social and economic importance, active tourism in Ukraine is still underdeveloped. The difficulties, encountered by active tourism in its development, are closely related, first of all, to the socio-economic problems of society development in the last decade of the 20th century, as well as to the internal organizational problems in the tourist movement in the 90 s of the 20 th century.

Analysis of the recent researches and publications. The issues are estudied by International Tourism Researchers Afanasiev O. O., Liubitseva V. F., Kifiak I. Yu., Malska I. G., Smirnov L. M., Ustimenko V. V. It is worth noting that in the recent years there has been a tendency that active (or adventure) tourism has become a separate segment of the industry. According to the UNWTO (World Tourism Organization), the capacity of the active tourism market in the US in 2017 amounted to more than \$110 billion. Among Americans, the most popular are diving with predators, rock jumps, rafting, as well as hiking and biking.

Task setting. Our main task is to monitor the current state and problems of active tourism in Ukraine. The work analyzes the possibilities of attracting citizens to useful, dynamic, mobile and rational use of leisure time by means of tourist leisure, ensuring optimal use of tourist resources, care for personal safety, promoting the health of tourists, protecting their rights, interests and property.

Main results. The peculiarity of active tourism is that the achievement of sports results is not its main goal, and therefore, it may be more widespread, accessible to the general public [3].

The studied branch of tourism includes improvement, restoration of forces, improvement of medical and physiological data by means of change of the forms of activity, dosed movement, rational nutrition, mental relaxation, better adaptation to unusual conditions; improvement of general and special physical training, development of endurance, agility, strength, balance; providing of practical skills in overcoming obstacles, mastering the technique of walking, skiing, cycling, rowing; mental improvement and emotional enrichment of the inner world of man, education of determination, courage, self-confidence, responsibility; expanding of the local lore, improving educational and methodological training, updating of the knowledge of geography, biology, history, ethnography and culture; mastering of the theoretical foundations of organizing and conducting hikes, 
developing routes, planning the work of tourist groups; gaining of sports experience participating in hiking.

In Ukraine, active tourism is developing as an integral part of the tourism industry and is aimed at promoting health, development of physical, moral, volitional and intellectual abilities of a person by involving in participation in sports trips of various complexity and competitions in the technique of sports tourism, amateur tourist trips, active traveling.

Currently, active tourism includes hiking, skiing, water, cycling, mountain, equestrian, auto and motorcycle tourism and speleotourism. The number of types of active tourism is constantly growing and diversifying.

Classification of the types of active tourism.

- Pedestrian terrestrial and underground types: hiking trips of different categories of complexity and target orientation (proper sports, recreational, recreational, historical, ecotourism, scientificexpeditionary, etc.), sports and tourist orientation, stationary (eco-resort) excursion-hiking, skiing, sport hunting and fishing, hunting, amateur harvesting (mushrooms, berries, char-potions), speleotourism and other traditional and modern-game types.

- Harness: riding (on horseback, mules, donkeys, camels, elephants), sledding (deer and dog harness), harness.

- Wheeled and mobile types: cycling, motorcycling, desert and wetland off-road rallies, snowmobiling and more.

- Mountain views: actually mountain tourism and mountaineering, rock climbing, skiing, modern skiing (slalom, snowboarding, etc.).

- Water types: yachting, catamarans, rowing boats of various (including archaic) structures, water skiing, scooter, scuba diving, scuba diving.

- Aerodynamic types: aeronautics, (delta, mono) gliding, travel on 1-2-seater sports planes, parachuting.

- Combined types of sports and recreational tourism and various types of sports and theatrical entertainments: expeditionary combination of mountain rafting with hiking, other forms of combination of water-pedestrian-harness tourism, theatrical reconstructions of historical battles, team battles, etc.

- Innovative kinds, extreme: robinzonada, single extemal expeditions (in tropical wilderness, in the mountain system, in the ocean, in the Arctic Circle, etc.), safaris, life in a backward tribe with active participation in ritual (including initial) native cults and so on.
Moreover, sports and amateur active tourism is an integral part of the domestic tourism industry, contributes to the development and distribution of active forms of recreation, and therefore, it performs recreational, educational, educational, economic and other functions. Developing on the boundaries of sports and active leisure in the natural environment, active tourism contributes to development of domestic tourism through the promotion of relatively cheap and simultaneously effective recreation, which, under conditions of low material income of a large part of the country population, gives it social and priority importance for the relevant state, public and commercial. Reducing the cost of recreation through the use of elements and means of sports tourism and minimizing the costs of material and technical infrastructure of such recreation relative to the cost of recreation by traditional organizational forms in domestic, foreign and international tourism, it is socially accessible and economically attractive to the average citizen.

Development of new directions of active tourism, particularly extreme, adventure, longdistance sailing and other trips, carrying out of combined types of tourism (automobile, bicycle, sailing, water, mountain, motorcycle, pedestrian, speleological, etc.) trips, using available natural and recreational and human resources of the country, does not only create the conditions for engaging in active tourism of the population of Ukraine, but also has a stimulating effect on the development of international and foreign tourism, contributes to the overall development of the tourism industry as a highly profitable sector of the Ukrainian economy and its entry into the world tourism market.

It worth noting that in the recent years, active tourism, as an effective means of attracting people to a healthy lifestyle, has received much more attention of public authorities.

Thus, it can be stated that by 2010 , active tourism has not only emerged from the crisis phase in its development, but also become recognized in the regions and generally in Ukraine as a type of recreation [2].

It is important to study the problem of impact of the tourist activities on nature. Some of the most common tourist activities include recreation, games, social meetings in nature. Finally, it will result in:

- trampling, damage to plants, soil from fires, deterrence of animals; 
- reduction of the number of mushrooms, berries, flowers;

- introduction of organic and inorganic materials (food waste, paper, metal, glass, etc.), new organic species (seeds, animals).

Among those, trampling is the worst effect.

Each persom leaves some traces on the environment. The soil is compacted, the litter is pressed, the stairs die; collection of mushrooms, berries, flowers reduces the possibility of self-renewal of plants; a broken branch, notch or notch on the trunk causes infection of the trees with diseases and pests. Definitely, the influence of one person or group of people from the outside is negligible, because eventually everything is restored to its previous state. However, with a mass influx of people, the processes of recovery are slower than the processes of destruction.

First of all, the forest floor is trampled on the sites that are intensively visited by tourists; its mass is reduced twice and more times. Many typical grasses disappear in the forests, and weeds appear in their place. Indigenous forest herbs, like snowdrops, shoots, anemones, blackberries and others, are brittle.

Other negative effects include clogging, which impairs the aesthetic appearance and hygiene of the environment. Due to the careless handling of fire, forest fires arise, which destroy landscapes and lead to erosion (due to the destruction of vegetation) [6].

Great damage to the environment is caused by unorganized auto and motorcycle tourism. The chaotic movement of cars and motorcycles off the roads leads to loosening of soil, destruction of grass, moss, berries, mushrooms. In the forests, on the meadows, cars leave particularly deep tracks or pull together with the roots the vegetation that holds the soil, break up the soil cover, turn it into an easily transportable material for wind and water. The stops and parking lots are polluted with engine oils, fuel, various cleaning products.

Different tourist activities have different environmental impacts. It can be zero (for example, the impact of surfing, ice skating on frozen rivers and lakes) or the highest degree of destruction and pollution of nature, which result in various mass recreational activities, games and meetings in the wild, auto and motor tourism [1].

These are the types of tourist holidays that have minimum or no environmental impact, and will use active tourism without harm to the environment.
Conclusions. In Ukraine, active tourism is being developed under the influence of a number of political and economic factors, which are conditioned by the transformation processes occuring in the country. On the one hand, they contributed to active development of the Ukrainian tourist market and the rapid growth of the share of outbound tourism, on the other - the economic crisis had a negative impact on formation of the tourism industry and its infrastructure, lacking confidence in the full implementation of strategic plans in the tourism sphere. The development of active tourism is essential for development of the Ukrainian economy. This type of tourism is suitable for new forms of ownership and can bring the greatest value.

However, the development of active tourism in Ukraine needs support, consistent development throughout the country's active tourism industry. Active tourism is one of the priority areas for development of domestic and foreign tourism in Ukraine, one of the most stable types of tourist markets. Thus, it can be stated that, in the recent years, active tourism has not only emerged from the crisis phase of its development, but also became a recognized type of recreation in the regions, and generally in Ukraine.

\section{References}

1. Bulashev A. Ya., Tonkoshkur M. V. Sport tourism. Kharkiv: KhSAFK, 2009. 120 p. (in Russian).

2. Culture of leisure / V. M. Pich et al. Kyiv, 1990. (in Russian).

3. Hrabovskyi Yu. A., Skaliy O. V., Skaliy T. V. Sports tourism. Ternopil: The Educational Book-Bohdan, 2008. 304 p. (in Ukrainian).

4. Hrishnova O. A. Tourism and Recreation as Factors of Human Development. Proceedings of the participants of the second scientific-practical conference "Information Technologies in the Management of Tourism and Resort and Recreational Economy" (September 15-16, 2006, Berdiansk). Berdiansk: ARIU AUIT, 2006. 245 p. (in Ukrainian).

5. Kifiak V. F. Organization of tourist activity in Ukraine: study. tool. Chernivtsi: Books-XXI, 2003. 300 p. (in Ukrainian).

6. Moskalets T. V. Tourism, as a recreational potential of the country. Bulletin of Chernihiv State Pedagogical University. 2012. Issue. 98. P. 262-266. (in Russian).

7. Tourism business in Ukraine: difficulties and prospects. Finance and credit information portal. URL: http://www.dpa.cv.ua/ekonomika/turisticheskiy-biznes-vukraine-trudnosti-i-perspektivyi.html (Last accessed: 15.05.2019). (in Russian). 